\title{
Statins: Promising Protective Shield against Doxorubicin Cardiotoxicity
}

\author{
Ali Shalizar Jalali* \\ Department of Basic Sciences, Urmia University, Iran
}

Submission: August 14, 2017; Published: August 28, 2017

*Corresponding author: Ali Shalizar Jalali, VMD, PhD, Histology and Embryology Research Laboratories, Department of Basic Sciences, Faculty of Veterinary Medicine, Urmia University, Urmia, Iran, Fax: 00984432771926; Tel: 00984431942593;

Email: ali_shalizar@yahoo.com/a.shalizar@urmia.ac.ir

\section{Opinion}

Doxorubicin (DOX) as a 40 year-old anthracycline antibiotic is a potent antineoplastic agent extensively used in the treatment of several malignancies [1]. Nevertheless, its clinical application carries the risk of serious non-target tissues toxicities, in particular cardiomyopathy, which manifests as life-threatening congestive heart failure [2]. It has been suggested that several mechanisms including reactive oxygen species over-generation, cardiomyocytes apoptosis, membrane-associated ion pumps dysfunction and topoisomerase II isoforms inhibition may be involved in DOX-induced cardiotoxicity [3-5].

To date, many studies have been carried out using adjunctive therapy to counteract DOX-evoked cardiac damages and it has been proposed that development of alternative cardioprotective strategies for management of DOX-related cardiotoxicity is inevitable [6-8]. However, only few therapeutic regimens have been proven to be useful in clinical practices.

Statins (STNs) as 3-hydroxy-3-methylglutaryl-CoAreductase inhibitors are first-line cholesterol-lowering agents with pleiotropic biological activities including antioxidant, antiinflammatory, anti-apoptotic and cytoprotective properties [913]. Accordingly, there is a growing body of evidence indicating that STNs as potent cardioprotective agents can protect cardiac tissue against DOX-induced damages along with potentiation of DOX-associated chemotherapies [14-16]. Recently, it has been reported that simvastatin can exert significant cardioprotective effects against DOX-related cardio toxicity through suppression of endoplasmic reticulum stress and activation of Akt signaling and its administration has been suggested as an encouraging approach to manage DOX cardiotoxicity [17].

As a final point, it seems that STNs could serve as safe and promising agents to prevent unfavorable cardiac complications in DOX therapies. Obviously, comprehensive retrospective and prospective clinical trials are needed to confirm the efficacy of STNs in improvement of DOX therapeutic utilities.

\section{References}

1. Lai HC, Yeh YC, Ting CT, Lee WL, Lee HW, et al. (2010) Doxycycline suppresses doxorubicin-induced oxidative stress and cellular apoptosis in mouse hearts. Eur J Pharmacol 644(1-3): 176-187.

2. Ferreira AL, Matsubara LS, Matsubara BB (2008) Anthracyclineinduced cardiotoxicity. Cardiovasc Hematol Agents Med Chem 6(4): 278-281.

3. Henninger C, Huelsenbeck S, Wenzel P, Brand M, Huelsenbeck J, et al. (2015) Chronic heart damage following doxorubicin treatment is alleviated by lovastatin. Pharmacol Res 91: 47-56.

4. Wu S, Ko YS, Teng MS, Ko YL, Hsu LA, et al. (2002) Adriamycin-induced cardiomyocyte and endothelial cell apoptosis: in vitro and in vivo studies. J Mol Cell Cardiol 34(12): 1595-1607.

5. Wallace KB (2007) Adriamycin-induced interference with cardiac mitochondrial calcium homeostasis. Cardiovasc Toxicol 7(2): 101-107.

6. Zhang X, ZhaO J, Tong N, Liao X, Wang E, et al. (2011) Berberine attenuates doxorubicin-induced cardiotoxicity in mice. J Int Med Res 39(5): 1720-1727.

7. Janeesh PA, Abraham A (2014) Robinin modulates doxorubicininduced cardiac apoptosis by TGF- $\beta 1$ signaling pathway in Sprague Dawley rats. Biomed Pharmacother 68(8): 989-998.

8. Dragojevic-Simic VM, Dobric SL, Bokonjic DR, Vucinic ZM, Sinovec SM et al. (2004) Amifostine protection against doxorubicin cardiotoxicity in rats. Anticancer Drugs 15(2): 169-178.

9. Iwata A, Shirai R, Ishii H, Kushima H, Otani S, et al. (2012) Inhibitory effect of statins on inflammatory cytokine production from human bronchial epithelial cells. Clin Exp Immunol 168(2): 234-240.

10. Deo SH, Fisher JP, Vianna LC, Kim A, Chockalingam A, et al. (2012) Statin therapy lowers muscle sympathetic nerve activity and oxidative stress in patients with heart failure. Am J Physiol Heart Circ Physiol 303(3): H377-H385.

11. Butterick TA, Igbavboa U, Eckert GP, Sun GY, Weisman GA, et al. (2010) Simvastatin stimulates production of the antiapoptotic protein Bcl-2 
via endothelin-1 and NFATc3 in SH-SY5Y cells. Mol Neurobiol 41(2-3): 384-391.

12. Najafi G, Jalali AS, Mohammadi M, Moeini-Moghaddam R (2014) Suppression of doxorubicin-induced apoptosis in mouse embryos by simvastatin. Iran J Immunol 11(Suppl 1): 638.

13. Jalali AS, Behfar M, Najafi G, Nourian A, Shahkarimi M, et al. (2016) The suppressive effects of simvastatin on fertility impairment induced by experimental unilateral testicular ischemia-reperfusion in mice. Caspian J Reprod Med 2(2): 11-15.

14. Huelsenbeck J, Henninger C, Schad A, Lackner KJ, Kaina B, et al. (2011) Inhibition of Rac1 signaling by lovastatin protects against anthracycline-induced cardiactoxicity. Cell Death Dis 2: e190.
15. Riad A, Bien S, Westermann D, Becher PM, Loya K, et al. (2009) Pretreatment with statin attenuates the cardiotoxicity of doxorubicin in mice. Cancer Res 69(2): 695-699.

16. Yoshida M, Shiojima I, Ikeda H, Komuro I (2009) Chronic doxorubicin cardiotoxicity is mediated by oxidative DNA damage-atm-p53apoptosis pathway and attenuated by pitavastatin through the inhibition of rac1 activity. J Mol Cell Cardiol 47(5): 698-705.

17. Liu D, Liu Y, Yi Z, Dong H (2016) Simvastatin protects cardiomyocytes from doxorubicin cardiotoxicity by suppressing endoplasmic reticulum stress and activating Akt signaling. Int J Clin Exp Med 9(2): 2193-2201.

This work is licensed under Creative Commons Attribution 4.0 License

DOI: $10.19080 /$ JOCCT.2017.07.555710

\section{Your next submission with Juniper Publishers will reach you the below assets}

- Quality Editorial service

- Swift Peer Review

- Reprints availability

- E-prints Service

- Manuscript Podcast for convenient understanding

- Global attainment for your research

- Manuscript accessibility in different formats ( Pdf, E-pub, Full Text, Audio)

- Unceasing customer service

Track the below URL for one-step submission https://juniperpublishers.com/online-submission.php 